\title{
Education Reform of E-commerce Based on the Concept of "Innovation, Creativity and Entrepreneurship"
}

\author{
Shengbo Shi \\ Institute of Information Technology, \\ Zhejiang Shuren University, \\ Zhejiang, 310015, China \\ shirleyssb@gmail.com
}

\begin{abstract}
E-commerce has shown the tendency of gradually replacing the traditional business and plays a more and more important role in the world. It is necessary to take the education reform on E-commerce to train the e-commerce talents to meet the demand of the enterprises. This paper will introduce the necessity of education reform on e-commerce, and analyze the current education problems. In paper, the education reform will be discussed based on the concept of "Innovation, Creativity and Entrepreneurship".
\end{abstract}

Keywords-E-commerce; education reform; introdaction to E-commerce; innovation;creativity; entrepreneurship

\section{INTRODUCTION}

With the global economy development and the technology innovation, e-commerce shows the vigor as a new form of business. It is shown that the e-commerce talent gap will be 500 million people in the future five years [1]. The main reason for that is: more and more traditional enterprises have transferred to electricity supplier channels while the e-commerce talent to provide professional network marketing operations services is scarcity. Therefore, in the E-commerce education, it should be more targeted and pay more attention in the actual operation of the Internet. Education reform on "E-commerce" can identify the clear direction to the major of E-commerce and guide the future development of e-commerce. Meanwhile, with the continuous development of e-commerce, the "Introduction to E-commerce" curriculum education has been applied in some related majors such as Marketing major. So the education reform on E-commerce is imperative. This paper introduces the necessary of education reform on e-commerce in Part I, and analyzes the current education problems in Part II. In Part III, the suggestions are shown to make the education reform on e-commerce.

\section{THE NECESSITY OF EDUCATION REFORM}

From the perspective of course category, "Introduction to E-commerce" is a professional basic course and theory -practice guideline to the E-commerce major. "Introduction to E-commerce" is a basic course for students to learn follow-up professional courses such as Network Marketing, E-commerce Logistics Management, E-commerce Security, Payment and Settlement Networks, Planning and Design in E-commerce Website. It takes a pivotal position in the entire e-commerce education system. Therefore, it is necessary to conduct
E-commerce education reform in order to make the students to establish e-commerce thinking, which will be applied in study of the subsequent professional courses [2].

From the perspective of course content, the characteristics of "Introduction to E-commerce" are comprehensive, practical and developmental. Therefore, in the education process, it is necessary to pay attention to the integration of cross-cutting in E-commerce, while strengthening the practice and focusing on new technologies, new business modes and new business concept. For example, with the development of e-commerce, the modes of e-commerce are changed a lot: the traditional modes such as B2B (Business to Business), B2C (Business to Consumer), $\mathrm{C} 2 \mathrm{C}$ (Consumer to Consumer) evolved out a lot of new modes such as B2T (Business to Team), O2O (Online to Offline), B2F (Business to Family-consumer), F2C (Factory to Consumers), B4C (Business for Consumer) and so on. Meanwhile, the hot research such as cloud computing, things internet, smart cities, big data also have a profound impact in e-commerce. Therefore, it is need to adopt new teaching methods and innovative the teaching reform.

From the perspective of course arrangement, "Introduction to E-commerce" is generally arranged in the first semester in sophomore year. At this stage, the e-commerce students are taking theoretical and practical preparation for National Collegiate E-commerce Competition on the topic of "Innovation, Creativity and Entrepreneurship". Therefore, E-commerce education should be combined with National Collegiate E-commerce Competition to cultivate the innovation, creativity and entrepreneurship to students. "Innovation, Creativity and Entrepreneurship" is also the guidance to E-commerce education.

\section{CURRENT ANALYSIS}

The following problems in the current education of E-commerce can be shown as below: Lecturers focus on theoretical teaching while students lack innovative thinking. Even though there are as many as one hundred kinds of textbooks on "Introduction to Electric Commerce" and lecturers can choose the textbook from all of them, most of the textbooks involved broad knowledge and each chapter in the textbook are little relevant and could be separated as a separate discipline. However, most of lecturers are teaching in accordance with the concept of textbook and the chapters are 
taught step by step. It will make students lose interest in E-commerce and limit the students' capability to think, analyze and solve problems. Therefore, it is necessary to change the "theory-centered" education mode in E-commerce and highlight the practical application part to clear the application feature of "E-commerce" [3].

The purpose of this research is to reform the education content, education arrangement, education methods, education evaluation, education feedback, textbook on E-commerce and other aspects to make the students in the major of E-commerce can master the basic knowledge, theory and the practical application of E-commerce, and help students become an "innovation, creativity and entrepreneurship" talents with E-commerce professional thinking.

\section{EDUCATION REFORM}

\section{A. Reform on Education Content}

E-Commerce curriculum can be roughly divided into the following modules by the level of knowledge and their internal relations, which is shown in Table I.: module of E-commerce understanding, module of E-commerce building, module of E-commerce application, module of E-commerce management. Meanwhile, in the education process, it is necessary to pay attention to education content updated due to the rapid development of e-commerce.

TABLE I. CURRICULUM CONTENT MODULES

\begin{tabular}{|c|c|}
\hline Modules & Content \\
\hline \multirow{3}{*}{ Understanding } & Introduction to E-commerce \\
\cline { 2 - 2 } & E-commerce modes:B2B $\backslash \mathrm{B} 2 \mathrm{C} \backslash \mathrm{C} 2 \mathrm{C}$ and so on \\
\cline { 2 - 2 } Building & Mobile-commerce \\
\cline { 2 - 2 } & Elanning and Design of Website \\
\cline { 2 - 2 } Application & Online shopping \\
\cline { 2 - 2 } & Online shop \\
\cline { 2 - 2 } & Online Marketing \\
\hline \multirow{2}{*}{ Management } & Planing for E-commerce \\
\cline { 2 - 2 } & Management for E-commerce \\
\hline
\end{tabular}

\section{B. Reform on Education Procedure}

E-commerce is a new mode of business with good prospects. The education of E-Commerce will introduce the systematic knowledge, the basic theory and related practices about e-commerce. The education is so comprehensive that it involves information technology, economics, management and so on, so it is difficulties for students to learn up. In the education process, it should take thinking training and proficiency training as the focuses and the main task of education should transform from one-way imparting knowledge into two-way communication and ability training. Through discussion, independent learning and new ideas exploring, it can enhance the interest of student in learning the E-commerce curriculum. Meanwhile, by changing the way of acquiring knowledge, students can learn the basic methods to use existing knowledge to find, analyze and solve problems in the area of e-commerce. In this way, the students get the skills and ability to E-commerce.
In the education reform on e-commerce, PBL [4-5] is used as the main method, which makes knowledge into project implementation and through the guidance of lecturers, students gather information about the projects to solve the problem, and finally complete the assigned projects. In the PBL, the students are the mainstay and the students completed one or several projects with a clear purpose independently or cooperatively to acquire the appropriate knowledge and skills while the lecturers are responsible for guiding students to do group discussions and case studies, to mobilize the initiative and fully tap the potential of students by experience sharing and issues discussing, to help students develop creative thinking skills. Lecturer's mission is to choose the appropriate projects for students based on the students' prior experience, knowledge and interests to put the students into the scenarios to explore knowledge and solve problems .The implementation of PBL is shown as the following steps:

Firstly, choose the most preferable projects. Selecting the appropriate projects is the key to successful education. Projects chosen are necessary to closely integrated with the education content, be able to mobilize the enthusiasm of students, and make the opportunity for students to field trips or participate in person.

Secondly, implement the projects by group. Once the topic of the project has been identified, the big project can be divided into multiple subprojects, which can be implemented in phases and by group based on the characteristics of the project. The students should report the project process and find the problems timely. In the implementation of the project, the students are the mainstay while the lecturer is responsible for organizing students into groups, guiding appropriately and providing the learning resources and construct collaborative environment.

Thirdly, inspect and evaluate the projects. Project inspection and evaluation is divided into multiple phases. Each sub-project should be review and assessment when it is completed. It is useful to discover and solve problems, learn mutual and share knowledge, and promote competition among groups to mobilize the interest in learning during the phase inspection and evaluation. Project evaluation of learning outcomes is not only to assessment the completion of the project, but also depends on the implementation process of the project.

\section{Reform on Education Methods}

Education methods adopted mainly are theoretical discussions method, cooperative seminars method, experimental method, and practice method [6-8].

1) Theoretical Discussions Method: The method focuses on the theory of knowledge. The lecturers can teach the integration and optimization content of the relevant knowledge, appropriate adjustment textbook chapters and put cases organically into each chapter or module according to the seminar theme and content module. In the process of education, it should be taken heuristics and problem-based teaching to avoid dogmatic. The lecturers should put questions to inspire 
students to think and discuss after one knowledge point is taught completed.

2) Cooperation Seminar Method: Each 4-5 people are grouped together to be a seminar team. Seminar methods can be divided into curricula seminar and extra-curricula seminar. In curricula seminar, the lecturers inspire students to discuss and choose the 1-2 groups to report the results for the students in the class to review and discuss in a wider range.

3) Experiment Method: The experimental education platform is taken to consolidate theoretical knowledge and train practical skills.

4) Practice Method: Visiting or participating in the E-commerce enterprises to clear the demand of e-commerce enterprises and enable enterprises to participate in the construction of E-commerce education.

\section{Reform on Examine}

The examination integrates e-commerce planning writing and experimental practice tests which can test students mastery of practical application. Overall result of the curriculum includes comprehensive e-commerce planning writing, seminars and other learning activities results and experimental practice scores.

\section{E. Reform on Education Feedback}

The following approaches are taken to collect the feedback of the education effects: instant communication tools, email, communicate to student directly by extracurricular and curricular answering questions and review, homework submitted, Group discussion presentation and so on.

\section{F. Reform on Auxiliary Experimenal System}

There are various of roles in a complete e-commerce system, so the reform project decompose the e-commerce system by the different roles to make students play the roles such as business, consumers, logistics and distribution companies, commodity trading center, marketing managers, production managers, inventory managers, financial managers to implement the e-commerce activities. The system can take advantage of some of the e-commerce website and relevant software to improve.

\section{G. Reform on Textbook}

In the education reform, the textbook is prepared in accordance with the application of e-commerce to guide students to be an "Innovation, Creativity and Entrepreneurship" talent.

\section{CONCLUSION}

E-commerce has shown the tendency of gradually replacing the traditional business and plays a more and more important role in the world. So it is nessesary to make the education reform to meet the demand for e-commerce talent. This paper shows the problems in cureent education and gives the suggestions based on the concept of "Innovation, Creativity and Entrepreneurship".

\section{REFERENCES}

[1] http://news.xinhuanet.com/hr/2012-06/07/c_123248730.htm[Z]. 2012.06.07.

[2] http://www1.lzcc.edu.cn/Teach/DianZiShangWu2/03.htm[Z].

[3] HUANG Zhi-ping, Reform and Innovation of Basic Course of Electrical Commerce Specialty_-From Electrical Commerce Principle to Electrical Commerce Planning and Implementation[J]. Vocational and Technical Education.2010(02).

[4] SHA Kai. The Application of PBL to Electronic Business Introduction[J]. Science and Technology of West China. 2007(17).

[5] TAN Zhong-fang,JIAO Zhen,WANG Yan-ping,LI Zong-wei, An Exploration of Teaching Reform in the E-commerce Course[J]. Journal of Luoyang Institute of Science and Technology(Social Science Edition). 2011(03).

[6] GUAN Wenjing, Exploration on E-commerce Curriculum Reform[J]. The Guide of Science \& Education. 2011(12).

[7] Liu Chunming;Meng Lingxi, Reform and Innovation of Training Mode of E-commerce Professionals in Independent Institute:Taking College of Humanities \& Information,Changchun University of Technology as the Example[J]. Value Engineering.2012(13).

[8] YAO Ju-ying,HONG Hua-xiu,XIA Ke-jian, The Analyses of the Performance of the Practice Teaching Innovation in Electronic Commerce[J]. Journal of Jiangxi Institute of Education. 2009(05). 